\title{
Wound healing promoting activity of Earthworm, Eutyphoeus gammiei (Beddard): in vitro studies on human skin keratinocyte cell line (HaCat).
}

\author{
Saha Susmita, Bhattacharjee Deepjyoti, Saha Anwesha, De Gahin, Saha Partha and Sil Samir Kumar* \\ Molecular Genetics and Cell Physiology Lab, Department of Human Physiology, Tripura University, Suryamaninagar, Tripura-799022, India.
}

\begin{abstract}
Earthworm, Eutyphoeus gammiei, homogenate (EGH) was screened for wound healing activity on human keratinocyte cell line, HaCat, by cell proliferation and migration assays. The maximum proliferation and migration of keratinocyte cells were observed at the dose of $25 \mu \mathrm{g} / \mathrm{ml}$. As cell proliferation and migration are key factors for wound healing, the study clearly suggests the potential role of earthworm species Eutyphoeus gammiei on wound healing.
\end{abstract}

Keywords: Eutyphoeus gammiei, Keratinocyte, MTT assay, scratch assay.

Article Info: Received 01 Oct, 2018; Review Completed 02 Nov 2018; Accepted 03 Nov 2018; Available online 15 Nov 2018

Cite this article as:

Saha S, Bhattacharjee D, Saha A, De G, Saha P, Sil SK, Wound healing promoting activity of Earthworm, Eutyphoeus gammiei (Beddard): in vitro studies on human skin keratinocyte cell line (HaCat)., Journal of Drug Delivery and Therapeutics. 2018; 8(6):155-158 D0I: http://dx.doi.org/10.22270/jddt.v8i6.2036

*Address for Correspondence:

Sil Samir Kumar, Molecular Genetics and Cell Physiology Lab, Department of Human Physiology, Tripura University, Suryamaninagar, Tripura-799022, India..

\section{INTRODUCTION}

Skin protects us from various environmental factors such as ionizing radiation, temperature, pressure, UV ray etc ${ }^{1}$. However, when this protective function of skin is lost due to physical, chemical or thermal injuries, it is called coetaneous wound ${ }^{2}$. After injury the wounded tissue initiates a cascade of biochemical events to repair the damaged region, known as wound healing process 3 . Wound healing is a well-regulated complicated process that involves interactions among resident and recruited cells such as epithelial cells, fibroblasts, endothelial cells, inflammatory cells, and interactions of those cells with extracellular matrix molecules, growth factors, cytokines, and chemokines ${ }^{4}$.

During healing process keratinocytes first migrates without proliferating 5 . After that keratinocyte proliferate in order to provide more cells for migration 6 . Before they begin migrating, keratinocytes change shape, becoming longer and flatter and extending cellular processes like lamellipodia and wide processes that look like ruffles $^{7}$. Actin filaments and pseudopodia form ${ }^{8}$. During migration, integrins on the pseudopod attach to the ECM, and the actin filaments in the projection pull the cell along9. The interaction with molecules in the ECM through integrins further promotes the formation of actin filaments, lamellipodia, and filopodia ${ }^{9}$. All these promote proliferation and migration of keratinocyte.
In China, Japan, Indonesia and the Far East, earthworms have been used to treat various chronic diseases since $1340 \mathrm{AD}^{10}$. The use of earthworm species as wound healing agent has been reported in various studies ${ }^{11-15}$. The medicinal property of earthworm may vary depending on the species and living environment of that organism ${ }^{16-19}$. Antibacterial and anti-inflammatory activities of the earthworm, E. gammiei, have been reported ${ }^{20,21}$. However, there is no scientific report about the wound healing activity of E. gammiei. Therefore, the present study was designed to evaluate the wound healing promoting activity of earthworm extract (E. gammiei) using human skin keratinocyte cell line.

\section{MATERIALS AND METHODS}

\section{Sample collection}

Adult earthworm Eutyphoeus gammiei was collected by hand sorting and digging method by spade from Agartala, Tripura at early morning.

\section{Preparation of tissue homogenate}

The tissue homogenate of Eutyphoeus gammiei (EGH) was made in $1 \mathrm{X}$ phosphate buffer solution ( $\mathrm{pH} 7.4$ ) according to the biochemical protocol. Specific amount of tissue was weighted to prepare $10 \%(\mathrm{w} / \mathrm{v})$ tissue homogenate using Potter Elvenjem glass homogenizer. Homogenate was filter sterilized and stored at $-20^{\circ} \mathrm{C}$ unit analyses ${ }^{20}$. 


\section{Protein estimation}

Protein content was estimated following Lowry's method ${ }^{22}$.

\section{Cell lines}

Human skin keratinocyte (HaCat) cell line was kind gift from Prof. Parimal Karmakar, Department of Life Science and Biotechnology, Jadavpur University, Kolkata, india.

\section{Cell culture}

Human skin keratinocyte (HaCat) cells were maintained in DMEM and supplemented with 10\% FBS, $100 \mathrm{IU} / \mathrm{mL}$ penicillin and $100 \mu \mathrm{g} / \mathrm{mL}$ streptomycin, at $37^{\circ} \mathrm{C}$ in a humidified atmosphere containing $5 \% \mathrm{CO}_{2}\left(\mathrm{CO}_{2}\right.$ incubator, ESCO, Singapore).

\section{Cell proliferation assay}

Cells were cultured in 96 well plates with or without different concentration of EGH for $24 \mathrm{~h}$ time duration. The cells viability was assessed using MTT assay method. 3[4,5-dimethylthiazol-2-yl]-2,5-diphenyltetrazolium bromide (MTT) was dissolved in phosphate-buffered saline at a concentration of $5 \mathrm{mg} / \mathrm{mL}$. MTT was added to each well, and plates were incubated at $37^{\circ} \mathrm{C}$ for $3 \mathrm{~h}$. The medium was replaced with $100 \mu \mathrm{L}$ DMSO, and the absorbance for each well will be measured at $570 \mathrm{~nm}$ on a microplate reader (BioTek, USA). Total viable cell count was taken at different time periods of $24 \mathrm{~h}, 48 \mathrm{~h}$ and $72 \mathrm{~h}^{23}$, 24 .

\section{Cell Migration assay}

Human skin keratinocyte (HaCat) cells were treated with EGH and an artificial wound was created on culture plates by scratching the plates through microtips. Microscopic images were taken immediately after wounding and during an incubation period of upto 72 hours. Finally the activity of the extract was compared with the control and measured by calculating the percentage of closed area ${ }^{25}$.

\section{Statistical analysis}

All data were represented as mean \pm SEM. Differences among groups were evaluated using one-way ANOVA to determine statistical significance. $\mathrm{P}<0.05$ was accepted as statistically significant. $\mathrm{P}<0.05, \mathrm{P}<0.01$ are represented by $*, * *$ and ${ }^{* * *}$, respectively.

\section{RESULTS}

\section{EGH stimulates keratinocyte proliferation}

MTT assay was used to examine the effect of EGH on human skin keratinocyte (HaCat) cells proliferation. The cells were treated with $3.125 \mu \mathrm{g} / \mathrm{ml}, 6.25 \mu \mathrm{g} / \mathrm{ml}, 12.5 \mu \mathrm{g} / \mathrm{ml}$, $25 \mu \mathrm{g} / \mathrm{ml}, 50 \mu \mathrm{g} / \mathrm{ml}$ and $100 \mu \mathrm{g} / \mathrm{ml}$ concentrations of EGH, and the cell viability was determined by MTT assay at $24 \mathrm{~h}$ and $48 \mathrm{~h}$. As seen in Table $1,25 \mu \mathrm{g} / \mathrm{ml}$ dose was found to be the optimal dose. At this dose after $24 \mathrm{~h}$ and $48 \mathrm{~h}$, the proliferation was increased up to $135 \%$ (p < 0.01) and $136 \%$ ( $p<0.001$ ). Thus EGH possesses the property of inducing proliferation of keratinocytes in dose and time dependent way.

Table 1: Effect of EGH on keratinocyte proliferation at different concentration

\begin{tabular}{|c|c|c|c|c|c|c|c|}
\hline \multicolumn{8}{|c|}{ Percentage of keratinocyte (HaCat) cell proliferation } \\
\hline & Cntrl & $\mathbf{3 . 1 2 5} \boldsymbol{\mu g}$ & $\mathbf{6 . 2 5} \boldsymbol{\mu g}$ & $\mathbf{1 2 . 5} \boldsymbol{\mu g}$ & $\mathbf{2 5} \boldsymbol{\mu g}$ & $\mathbf{5 0} \boldsymbol{\mu g}$ & $\mathbf{1 0 0} \boldsymbol{\mu g}$ \\
\hline $\mathbf{2 4}$ Hour & $100 \pm 0.1$ & $110 \pm 1.6$ & $120 \pm 1.7^{*}$ & $124 \pm 2.1^{*}$ & $135 \pm 1.7^{* *}$ & $120 \pm 1.8^{* *}$ & $108 \pm 1.9$ \\
\hline $\mathbf{4 8}$ hour & $100 \pm 0.2$ & $110 \pm 1.4$ & $120 \pm 1.4^{*}$ & $127 \pm 1.8^{* *}$ & $136 \pm 2.5^{* * *}$ & $117 \pm 1.9$ & $108 \pm 2.3$ \\
\hline
\end{tabular}

Data are expressed as the means \pm SD of three independent experiments, and the statistical significance was calculated using one way ANOVA, $\mathrm{n}=3$. $^{* *}(\mathrm{p}<0.05),{ }^{* *}(\mathrm{p}<0.01)$ and ${ }^{* * *}(\mathrm{p}<0.001)$ in comparison to control (without extract).

\section{EGH increases Keratinocyte Migration}

In the in vitro wound model scrape wounds were generated in nearly confluent monolayer of cells and the migration of the edge of the wound was monitored with a phase contrast microscope. Cells with or without EGH treatment were allowed to migrate into the void area for $0-72 \mathrm{~h}$. The keratinocyte cells started to migrate into the void area at
$24 \mathrm{~h}$ after EGH treatment and wound area clouses up to $80 \%$ compared to respective wound area, and the void area of the cells was almost closed at $48 \mathrm{~h}$. In contrast, the migration of untreated cells was slower at the corresponding time points. The gap width at each time point after treatment with EGH was measured and plotted in Fig 1. 


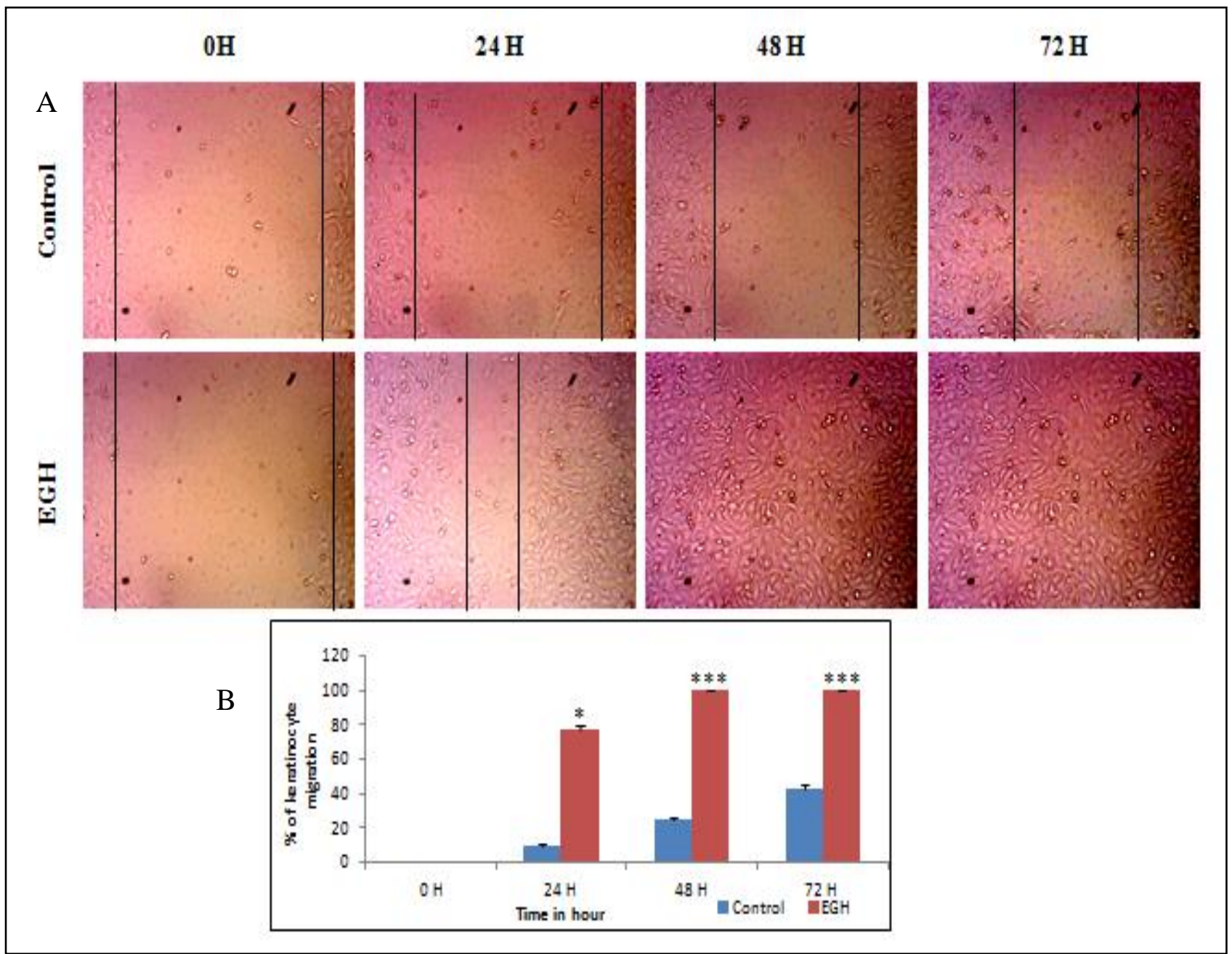

Figure 1: EGH induced migration of keratinocyte in an in vitro wound model. The wound is generated in monolayer cells and (A) photographed with a phase contrast microscope $(10 \mathrm{X})$ immediately after wounding $(0 \mathrm{~h})$ and 24,48 and $72 \mathrm{~h}$ later. Gap of the wound areas were measured using ImageJ Software, and (B) \% of wound closure with time is calculated. Data are expressed as the means \pm SD of three independent experiments, and the statistical significance was calculated using one way ANOVA. $\mathrm{n}=3$ ** $(\mathrm{P}<0.05),{ }^{* *}(\mathrm{P}<0.01)$ and ${ }^{* * *}(\mathrm{P}<0.001)$ in comparison to control (without extract). h, hour.

\section{DISCUSSION}

Nonhealing wounds are a major health problem worldwide ${ }^{26}$. The number is likely to grow due to age related conditions and pathologies such as diabetes, obesity, and cardiovascular diseases ${ }^{27}$. In China, Japan, Indonesia and the Far East, earthworms have been used to treat various chronic diseases since $1340 \mathrm{AD}^{10}$. The use of earthworm as, anti-microbial, anti- inflammatory, anti cancer, anti-pyretic, analgesic, nerve diseases have been reported in various studies. The medicinal property of earthworm may vary depending on the species and living environment of that organism ${ }^{16-19}$. The earthworm, $E$. gammiei possess the antibacterial and anti-inflammatory activity ${ }^{20,21}$. Therefore, the present study was designed to evaluate the wound healing property of E. gammiei.

Human keratinocyte cell line was used for this study. Keratinocytes are the major cellular component of the epidermis and are responsible for barrier restoration upon injury through a process known as epithelialisation ${ }^{28}$. The cellular and molecular processes involved in initiation, maintenance and completion of epithelialisation are essential for successful wound closure 29 . During regeneration of epidermis after wounding, activation, proliferation and migration of keratinocytes towards wounded area from the surrounding epidermis takes place $^{30}$. As depicted in Table 1 and Fig 1, EGH time and dose dependently increased the rate of proliferation and migration into wounded area and $25 \mu \mathrm{g} / \mathrm{ml}$ found to be the optimum dose for both proliferation and migration of keratinocyte. Therefore, the present work shows potent wound healing activity of E. gammiei and provides convincing scientific basis regarding the age old ethnomedicinal use of earthworm for wound healing.

\section{CONCLUSION}

This study provides scientific basis for the wound healing property of the earthworm E. gammiei.

\section{COFLICT OF INTERESTS}

The authors declare that there is no conflict of interests regarding the publication of this paper.

\section{ACKNOWLEDGEMENT}

We thankfully acknowledge Department of Biotechnology, Govt. of India (DBT Sanction Order No. BT/468/ NE/TBP/2013 and Dated-13/3/2014), for financial support. We acknowledge State Biotech hub, Tripura University, for technical support. 


\section{REFFERENCES}

1. Tortora G. J. and Grabowski S. R. Principle of Anatomy and Physiology. John Willey and sons Inc, USA, 2003; 12:1-27.

2. Gupta L. C., Gupta K. and Gupta A., New concise medical dictionary, AITBS, 2008; $4^{\text {th }}$ edition.

3. Gurtner G. C., Werner S., Barrandon Y., Longaker M. T. Wound repair and regeneration. 2008; 453 (Suppl.):314-321.

4. Martin P. Wound healing-aiming for perfect skin regeneration. Science. 1997; 276:75-81.

5. Ruszczak, Z. Efect of collagen matrices on dermal wound healing. Advanced Drug Delivery Reviews. 2003; 55 (12):1595-1611.

6. Expert Reviews in Molecular Medicine. The phases of coetaneous wound healing. Cambridge University Press. 2008; $5: 1$.

7. Mercandetti M., Cohen A. J. Wound Healing: Healing and Repair Emedicine.com. 2008.

8. Lorenz H. P. and Longaker M. T. Wounds: Biology, Pathology, and Management. Stanford University Medical Center . 2003.

9. de la Torre J., Sholar A. Wound healing: Chronic wounds Emedicine.com. 2006.

10. Stephenson J. The Oligochaeta, Oxford University Press, London. 1930.

11. Deng Z., Yin Y., Luo W., Kotian R. N., Gao S. S., Yi Z., Xiao W. F., Li W. P. and Li Y. S. The effect of earthworm extract on promoting skin wound healing. Bioscience Reports 2018; 38.

12. Mirjana M. P., Maja T., Vedran M., Grdis M.. Influences of earthworm extract G-90 on haematological and haemostatic parameters in Wistar rats. European Review for Medical and Pharmacological Sciences 2011; 15(1):71-78.

13. Shuliang S., Wang Y., Ji K., Liang H. and Ji A. Effect of earthworm active protein on fibroblast proliferation and its mechanism, Pharmaceutical Biology 2012; 54(4):732-739.

14. Chang Y.M.,1, Shih Y. T., Chen Y. S., Liu C. L., Fang W. K., Tsai C. H., Tsai F. J. And Huang C. Y. Schwann cell migration induced by earthworm extract via activation of PAs and MMP2/9 mediated through ERK1/2 and p38. Evidence-Based Complementary and Alternative Medicine 2011; 2011:395458.

15. Amarpal A., Singh R., Aithal H. P., Kinjavdekar P., Pawde A., Singh K. P. and M. Gugjoo. Evaluation of the healing potential of earthworm coelomic fluid in full thickness skin wounds in rabbits. Veterinarski Arhiv 2015; 85(2):189-200.

16. Cooper E. L., Balmuragun M., Parthasarathi K. and Ranganathan L. S. Earthworm paste (Lampito maurtill, Kinberg) alters inflammatory, oxidative, haematological and serum biochemical indices of inflamed rat. European Review for Medical and Pharmacological Sciences 2007; 2(2):77-99.

17. Chen C. T., Lin J. G., Lu T. W. Earthworm extracts facilitate pc12 cell differentiation and promote axonal sprouting in peripheral nerve injury. The American Journal of Chinese Medicine. 2010; 38(3):547-560.
18. Liu C. H., Lin Y. W., Tang N. Y. Effect of oral administration of Pheretima Aspergillum (Earthworm) in rats with cerebral infarction induced by middle-cerebral artery occlus. African Journal of Traditional Complementary and Alternative Medicines 2013; 10:66-82.

19. Noda N., Tsunefuka S., Tanaka R. and Miyahara K. Effect of an earthworm, Lumbricus rubellus, Chem Pharm. Bull. 1992; 40:2756.

20. Debnath M., Gosh R., Bhattacharjee D., and Sil S. K. Anti inflammatory effect of extract of earthworm- Eutyphoeus gammiei from Tripura, north eastern India. IJPBS 2018; 8(2):622-627.

21. Debnath M., Ray Choudhury P., and Sil S. K. Studies on NS5 18 S RDNA based molecular phylogenetic analysis and antibacterial properties of Eutyphoeus gammiei, an earthworm species endemic to Northeast India. World Journal of Pharmacy and Pharmaceutical science 2016; 5(2):1357-1364.

22. Mosmann T. Rapid colorimetric assay for cellular growth and survival: application to proliferation and cytotoxicity assays. J of Immunological Methods. 1983; 65(1-2):55-63.

23. Krishnamoorthy J. R., Sumitira S., Ranjith M. S., Gokulshankar S., Ranganathan S., Mohanty B. K., Prabhakaran G. An in vitro study of wound healing of a polyherbal formulation as evidence by enhanced cell proliferation and cell migration. EDOJ. 2012; 8(1):1.

24. Ebeling S., Naumann K., Pollok S., Wardcki T., Merfort I., Brandner J. M. From a traditional medicinal plant to a rational drug: Understanding the clinically proven wound healing efficacy of Birch Bark Extract. Plos one 2014; 9(1):e86147.

25. Lowry O.H., Rosebrough N. J., Farr A. L. and Randall R. J. Protein measurement with folin phenol reagent. The Journal of Biological Chemistry 1951; 193:265-275.

26. Fronza M., Heinzmann B., Hamburger M., Laufer S., Merfort I. Determination of thewound healing effect of Calendula extracts using the scratch assay with 3T3 fibroblasts. J Ethnopharmacol 2009; 126:463-467.

27. Sen C. K., Gordillo G. M., Roy S., Kirsner R., Lambert L., Hunt T. K. Human skin wounds: a major and snowballing threat to public health and the economy. Wound repair regeneration 2009; 17 (Suppl.):763-71.

28. Novl B., Vinod P. K., Freire P. and Kapuy O. Systems-level feedback in cell-cycle control. Biochemical Society Transactions 2010; 38(5):1242-1246.

29. Miguel S. M. S., Opperman L. A., Allen E. P., Zielinski J. and Svoboda K. K. H. Bioactive antioxidant mixtures promote proliferation and migration on human oral fibroblasts. Archives of Oral Biology 2011; 569 (8):812-822.

30. Chmielowiec J., Borowiak M., Morkel M., Stradal T., Munz B., Werner S., Wehland J. and Birchmeier W. c-Met is essential for wound healing in the skin. The Journal of Cell Biology 2007; 177(1):151-162. 